\title{
Virtual Laboratory berbasis PhET Simulation Untuk Menentukan Konstanta Wien
}

\author{
Purnama Ainun Nisa ${ }^{1}$, Puspita Yuma $\mathrm{Sari}^{2}, \mathrm{Nana}^{3}$ \\ Pendidikan Fisika, FKIP Universitas Siliwangi \\ Tasikmalaya, Jawa Barat, Indonesia 46115 \\ Nisaming19@gmail.com
}

\begin{abstract}
Abstrak
Penelitian ini bertujuan untuk menentukan nilai konstanta Wien dengan menggunakan virtual laboratory yaitu PhET Simulation. PhET merupakan rangkaian simulasi interaktif yang sangat menguntungkan dalam pengintegrasian teknologi komputer ke dalam pembelajaran atau eksperimen. Alat dan bahan yang digunakan pada eksperimen ini diantaranya yaitu laptop dan software PhET Simulation. Metode yang digunakan dalam analisis data adalah dengan analisis regresi liniear yaitu hubungan antara panjang gelombang dengan suhu. Nilai a sebesar 0.014 dengan besarnya nilai Konstanta Wien dari data tersebut $2.898 \times 10^{-3} \mathrm{~m} . \mathrm{K}$ dengan ralat relatif sebesar $5 \%$ atau 0,05. Hal ini sesuai dengan nilai teori yaitu $2.898 \times 10^{-3} \mathrm{~m} . \mathrm{K}$ dan membuktikan bahwa dengan menggunakan PhET Simulation sangat efektif untuk analisis eksperimen.
\end{abstract}

Kata kunci: virtual laboratory, PhET Simulation, konstanta Wien.

\section{Pendahuluan}

Menurut Jaja Kustija benda hitam dapat didefinisikan sebagai benda dimana radiasi yang jatuh akan diserap seluruhnya (tidak ada yang dipantulkan). Benda hitam sempurna sukar didapatkan jelaga yang sangat hitam masih mempunyai daya pantul meskipun kecil sekali. Suatu lubang kecil pada sebuah dinding berongga dapat dianggap sebagai benda hitam sempurna. Sinar yang masuk pada dinding berongga dengan lubang kecil sinar akan dipantulkan berkali-kali oleh dinding berongga dan setiap kali dipantulkan intensitasnya selalu berkurang (karena sebagian sinar diserap dinding) sampai suatu saat energinya kecil sekali (hampir nol). Jadi dapat dikatakan bahwa sinar yang mengenai lubang tidak keluar lagi, itulah sebabnya lubang ini dinamakan benda hitam. Semakin kecil lubang semakin mirip dengan benda hitam sempurna (karena semakin sedikit peluang keluarnya sinar tersebut).

Pada saat benda hitam atau benda berongga dipanaskan maka dinding sekeliling rongga akan memancarkan radiasi dan memantulkan sebagian radiasi yang datang (dan menyerap sisanya). Peristiwa penyerapan dan pemancaran oleh tiap-tiap bagian dinding berongga akan berlangsung terus menerus hingga terjadi kesetimbangan termal. Pada keadaan seimbang termal suhu bagian dinding yang sudah sama besar sehingga radiasi yang dipancarkan sama dengan energi yang diserapnya, dalam keadaan ini didalam rongga dipenuhi oleh gelombang- 
gelombang yang dipancarkan oleh tiap titik pada dinding rongga. Radiasi dalam rongga ini disebut uniform. Jika dinding diberi sebuah lubang maka radiasi ini akan keluar dari lubang radiasi yang keluar, ini dapat dianggap sebagai radiasi benda hitam.

Sedangkan menurut Erwin Sutarno dan Hayat, M S benda hitam didefinisikan sebagai suatu benda yang menyerap seluruh radiasi elektromagnetik yang jatuh kepadanya dan tidak ada radiasi yang dapat keluar atau dipantulkannya. Itu sama seperti pernyataan sebelumnya diatas yang berarti benda hitam mempunyai harga absorptansi dan emisivitas yang besarnya sama dengan satu.

Radiasi matahari merupakan yang termasuk salah satu radiasi elektromagnetik. Dimana radiasi matahari adalah pancaran partikel yang berasal dari proses thermonuklir yang terjadi di matahari. Sinar matahari yang memasuki permukaan bumi memiliki berbagai macam panjang gelombang yaitu, Sinar tampak yang berada pada panjang gelombang antara $400-700 \mathrm{~nm}$, sinar inframerah pada panjang gelombang di atas $700 \mathrm{~nm}$ dan sinar ultraviolet pada panjang gelombang di bawah $400 \mathrm{~nm}$. Jumlah total radiasi matahari yang dapat diterima di permukaan bumi tergantung pada jarak matahari, intensitas radiasi matahari, panjang hari (sun duration), dan pengaruh atmosfer. Atmosfer dipanasi ketika radiasi gelombang panjang dari bumi diserap di atmosfer yang memberikan nilai persentase total radiasi yang dipantulkan oleh permukaan bumi yang disebut albedo.

Maka dari itu untuk menentukan panjang gelombang radiasi matahari yang sampai pada atmosfer bumi yaitu salah satunya menggunakan media yang tepat untuk eksperimen tersebut dalam fisika yaitu dengan laboratorium virtual. Laboratorium virtual berpotensial untuk memberikan peningkatan secara signifikan dan pengalaman belajar yang lebih efektif. Laboratorium virtual yang akan digunakan peneliti yaitu laboratorium virtual berbasis phET simulation.

Simulasi Physics Education Technology (PhET) adalah suatu simulasi interaktif di internet dengan memakai bahasa pemograman java dan flash, yang dikembangkan oleh tim dari Universitas Colorado Amerika Serikat. PhET telah mengembangkan serangkaian simulasi interaktif yang sangat menguntungkan dalam pengintegrasian teknologi komputer ke dalam pembelajaran (Prihatiningtyas S, Prastowo T, and Jatmiko B. 2013).

PhET juga menyediakan berbagai eksperimen jika di laboratorium alat dan bahan kurang memadai. PhET menekankan hubungan antara fenomena kehidupan nyata dengan ilmu yang mendasari, mendukung pendekatan interaktif dan kontrukvis, memberikan umpan balik, dan menyediakan tempat kerja. Kelebihan dari simulasi PhET yakni dapat melakukan percobaan secara ideal, yang tidak dapat dilakukan dengan menggunakan alat yang sesungguhnya. Dipilihnya simulasi PhET ini karena simulasi ini berbasis program java yang memiliki kelebihan yakni easy java simulation (ejs) yang dirancang khusus 
untuk memudahkan analisis konsep fisika dalam bentuk simulasi fisika dengan memanfaatkan komputer. Dengan phET simulation analisis - analisis fisika yang dilakukan diharapkan mampu menjelaskan konsep - konsep abstrak menjadi nyata

\section{Metode}

Pada penelitian ini menggunakan metode eksperimen berbasis software. Software yang digunakan yaitu PhET simulation. Instrumen lain yang digunakan sebagai pendukung penelitian ini berupa lembar analisis untuk menentukan konstanta Wien. Selain itu metode yang digunakan pada penelitian penentuan konstanta Wien yaitu dengan menggunakan persamaan linear atau garis lurus model $\mathrm{y}=\mathrm{ax}$, dimana $\mathrm{x}$ adalah variabel bebas yang terletak pada sumbu datar, dan y adalah variabel terikat yang terletak pada sumbu tegak, a adalah kemiringan (gradien).

\section{Hasil dan Pembahasan}

Dari hasil analisis data diperoleh nilai a sebesar 0.014 dengan besarnya nilai Konstanta Wien dari data tersebut $2.898 \times 10^{-3} \mathrm{mK}$ dengan ralat relatif sebesar 5\% atau 0,05, dengan bantuan PhET Simulation, maka diperoleh data pada berbagai suhu yaitu pada suhu 3000 K, 4000 K, 5000 K, 6000 K, dan 7000 K. Percobaan penentuan nilai Konstanta Wien yang diperoleh dengan menggunakan Virtual Laboratory berbasis PhET Simulation terbukti mampu menganalisis dan meneliiti Konstanta Wien secara efektif karena tidak memerlukan banyak waktu untuk menganalisisnya. Hasil yang diperoleh sesuai dengan nilai teori.

Pada suhu $3000 \mathrm{~K}$ untuk analisis konstanta Wien pada PhET Simulation ditampilkan seperti pada gambar 1 diperoleh besarnya panjang gelombang $(\lambda)$ sebesar $966 \mathrm{~nm}$.

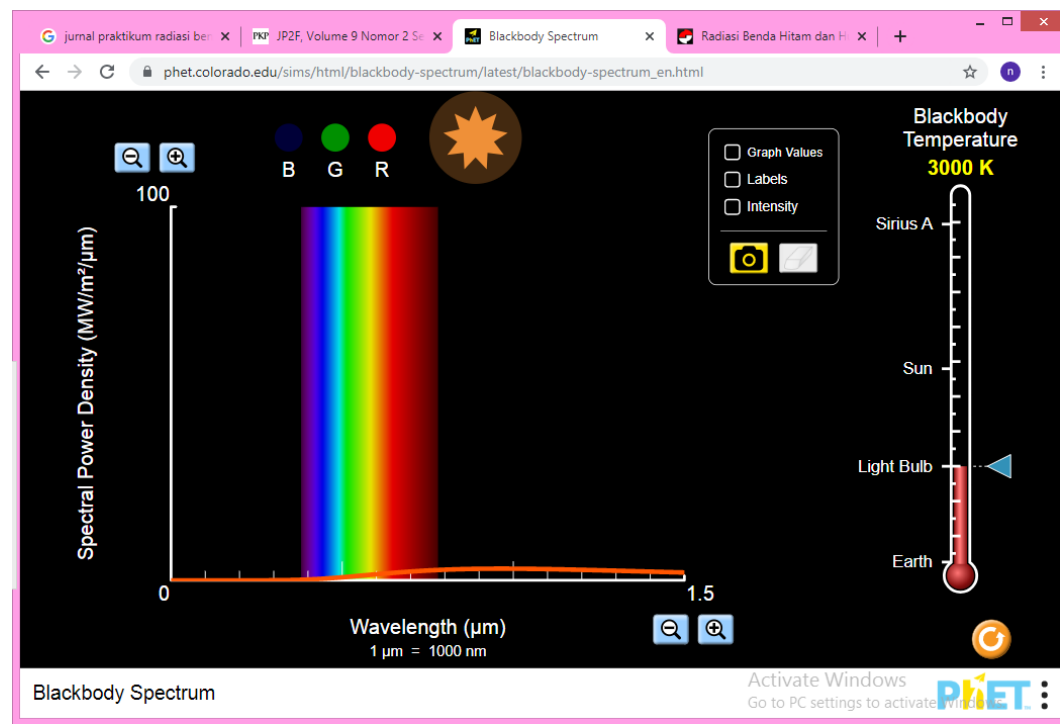

Gambar 1. Analisis konstanta Wien pada suhu $3000 \mathrm{~K}$ 
Pada suhu $4000 \mathrm{~K}$ untuk analisis konstanta Wien pada PhET Simulation ditampilkan seperti pada gambar 2 diperoleh besarnya panjang gelombang $(\lambda)$ sebesar $725 \mathrm{~nm}$.

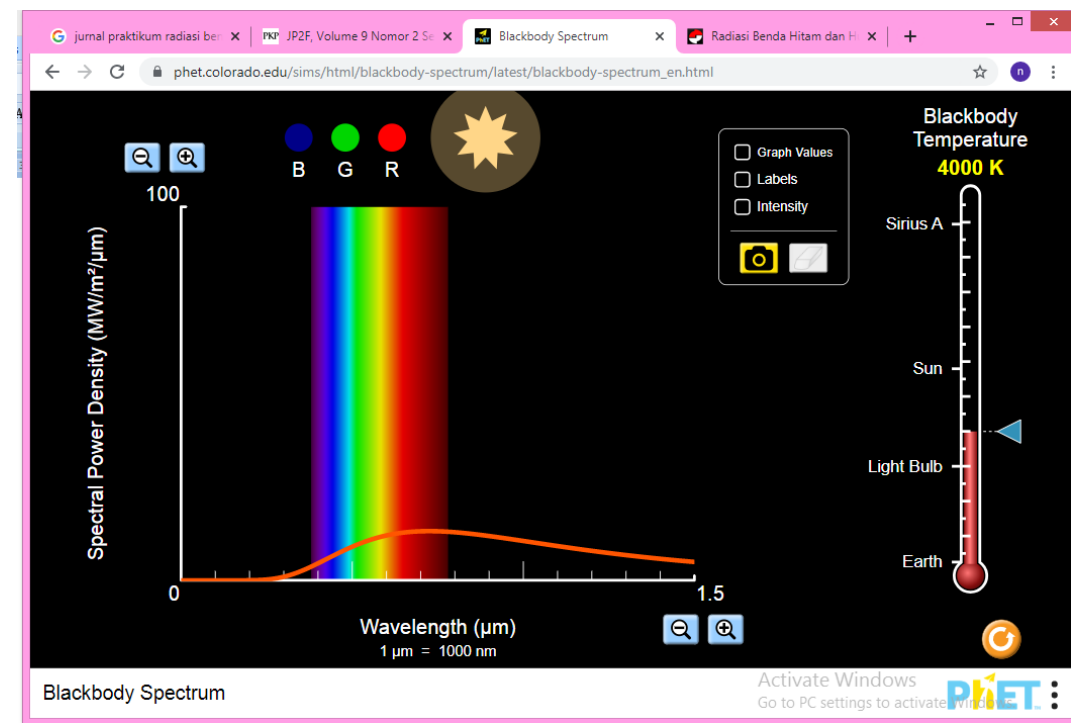

Gambar 2. Analisis konstanta Wien pada suhu $4000 \mathrm{~K}$

Pada suhu $5000 \mathrm{~K}$ untuk analisis konstanta Wien pada PhET Simulation ditampilkan seperti pada gambar 3 diperoleh besarnya panjang gelombang $(\lambda)$ sebesar $580 \mathrm{~nm}$.

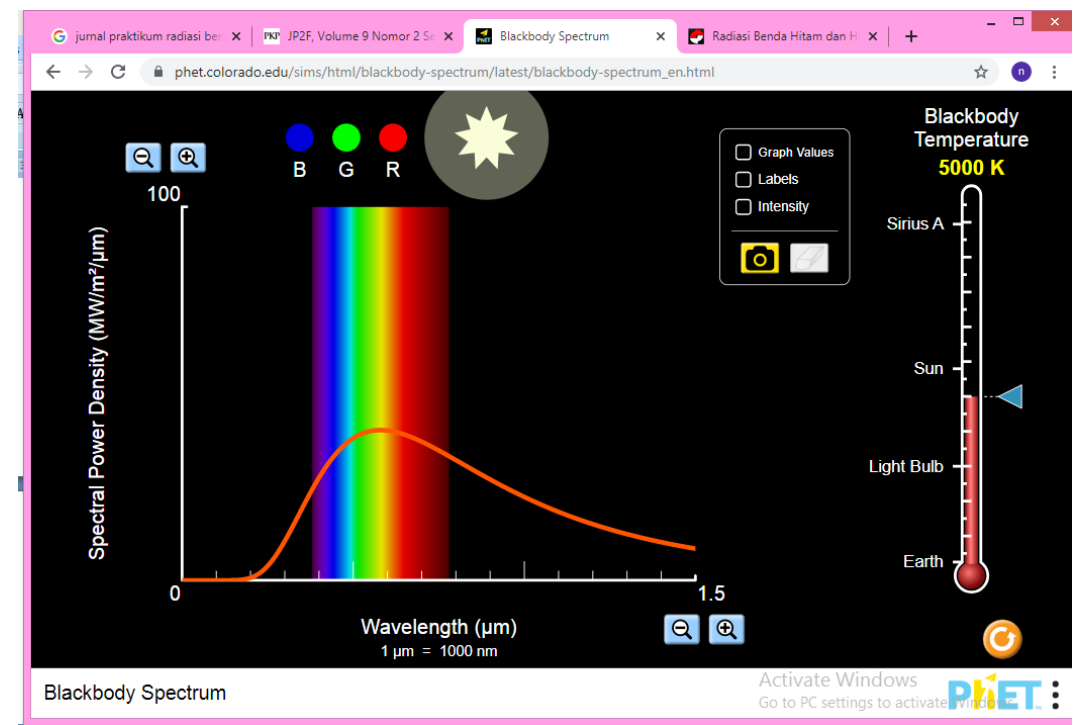

Gambar 3. Analisis konstanta Wien pada suhu $5000 \mathrm{~K}$

Pada suhu $6000 \mathrm{~K}$ untuk analisis konstanta Wien pada PhET Simulation ditampilkan seperti pada gambar 4 diperoleh besarnya panjang gelombang $(\lambda)$ sebesar $483 \mathrm{~nm}$. 


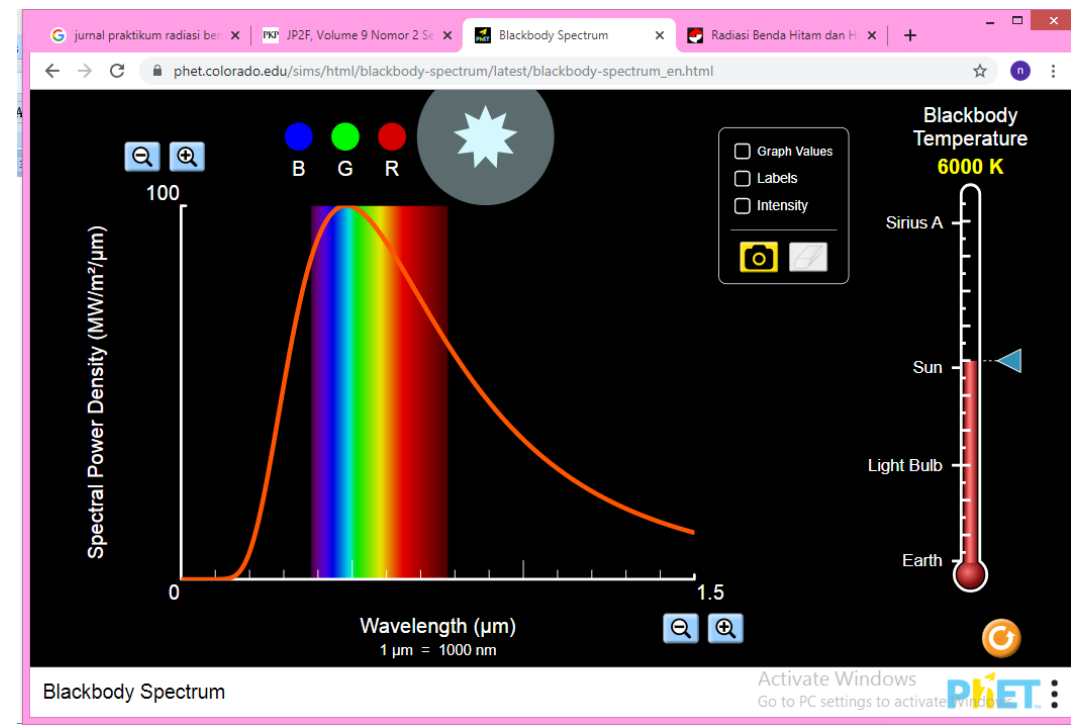

Gambar 4. Analisis konstanta Wien pada suhu 5860 K

Pada suhu $7000 \mathrm{~K}$ untuk analisis konstanta Wien pada PhET Simulation ditampilkan seperti pada gambar 5 diperoleh besarnya panjang gelombang $(\lambda)$ sebesar $414 \mathrm{~nm}$

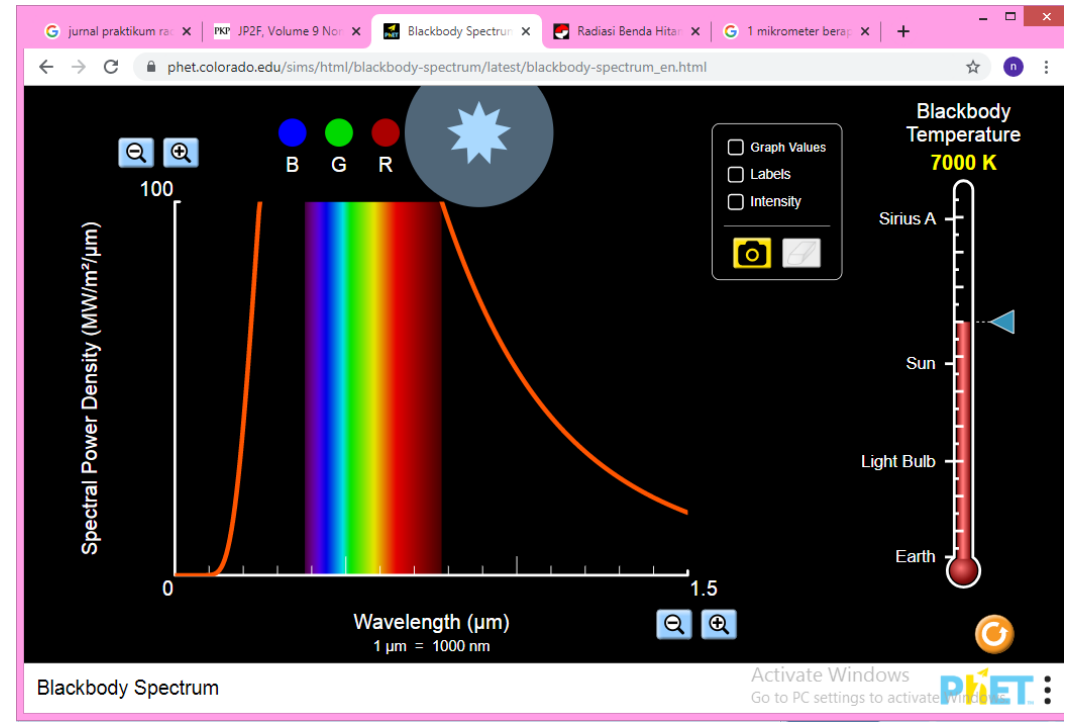

Gambar 5. Analisis konstanta Wien pada suhu 7000K

Setelah dianalisis menggunakan PhET Simulation, maka diperoleh hubungan antara suhu $(\mathrm{K})$ dan panjang gelombang $(\lambda)$ seperti pada tabel 1.

Tabel 1. Data nilai suhu $(\mathrm{K})$ dan panjang gelombang $(\lambda)$

\begin{tabular}{|l|l|l|}
\hline No. & $\mathrm{T}(\mathrm{K})$ & $\lambda$ (panjang gelombang) \\
\hline 1. & 3000 & $0.000966 \mathrm{~m}$ \\
\hline 2. & 4000 & $0.000725 \mathrm{~m}$ \\
\hline 3. & 5000 & $0.000580 \mathrm{~m}$ \\
\hline 4. & 6000 & $0.000483 \mathrm{~m}$ \\
\hline
\end{tabular}




\begin{tabular}{|l|l|l|}
\hline 5. & 7000 & $0.000414 \mathrm{~m}$ \\
\hline
\end{tabular}

Dari tabel 1, dapat diubah ke dalam persamaan regresi linier, sehingga diperoleh hubungan antara satu per suhu $\frac{1}{T}$ dan panjang gelombang $(\lambda)$ berikut ini.

Tabel 2 . Data nilai satu per suhu $1 / \mathrm{T}(\mathrm{K})$ dan panjang gelombang $\lambda(\mathrm{m})$

\begin{tabular}{|l|l|l|}
\hline No. & $1 / \mathrm{T}(1 / \mathrm{K})$ & $\lambda$ (panjang gelombang) \\
\hline 1. & 0.000333 & $0.000966 \mathrm{~m}$ \\
\hline 2. & 0.00025 & $0.000725 \mathrm{~m}$ \\
\hline 3. & 0.0002 & $0.000580 \mathrm{~m}$ \\
\hline 4. & 0.000167 & $0.000483 \mathrm{~m}$ \\
\hline 5. & 0.000143 & $0.000414 \mathrm{~m}$ \\
\hline
\end{tabular}

Dari data hasil pengukuran regresi linear seperti pada tabel 2 dapat dibuat grafik hubungan antara satu per suhu $1 / \mathrm{T}(\mathrm{K})$ dan panjang gelombang $\lambda(\mathrm{m})$. Dapat dilihat hubungan antara panjang gelombang dengan suhu yaitu berbanding terbalik, semaki besar suhunya maka panjang gelombangnya semakin kecil.

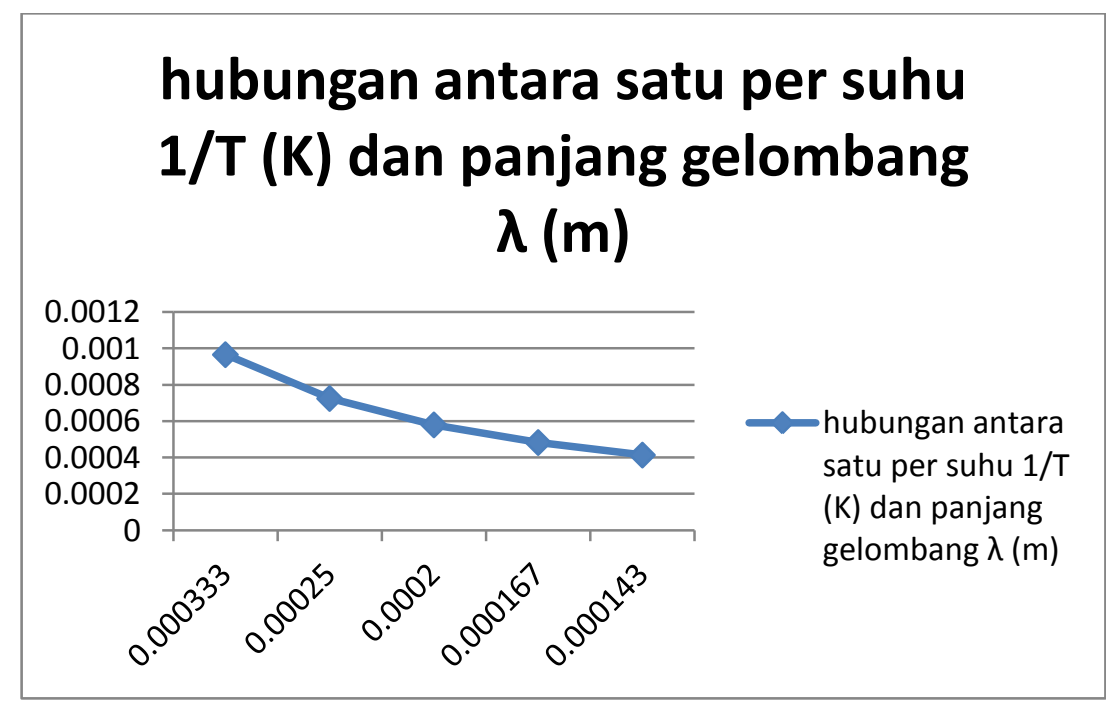

Gambar 6. Grafik hubungan antara satu per suhu 1/T (K) dan panjang gelombang $\lambda$

Untuk menganalisis eksperimen fisika pada konsep Blackbody Spectrum khususnya pada Konstanta Wien pada penelitian ini menggunakan virtual laboratory berbasis PhET Simulation.

Penelitian dilakukan dengan cara membuka aplikasi PhET Simulation di laptop dengan memilih konsep Blackbody Spectrum. Kemudian atur suhu sesuai yang diinginkan dengan memilih data sebanyak lima kali. Setelah plot suhu maka akan diperoleh panjang gelombang yang diperoleh pada saat suhu tertentu. 
Data suhu dan panjang gelombang tersebut kemudian dianalisis untuk memperoleh nilai Konstanta Wien.

Dengan rumus persamaan:

$$
\lambda=C \cdot \frac{1}{T}
$$

Dengan: $\lambda=$ panjang gelombang cahaya maksimum $(\mathrm{m}), \mathrm{C}=$ nilai konstanta pergeseran Wien $(\mathrm{m} . \mathrm{K})$, dan $\mathrm{T}=$ suhu $(\mathrm{K})$.

Maka diperoleh persamaan regresi linear:

$\mathrm{y}=\mathrm{ax}$

dengan memisalkan $\frac{1}{T}=\mathrm{x}$ dan $\lambda=\mathrm{y}$. Adanya pengaruh suhu akan menimbulkan perubahan panjang gelombang maksimum pada radiasi benda hitam, sehingga suhu sebagai variabel bebas dan panjang gelombang sebagai variabel terikat. Maka diperoleh persamaan gradien:

$\mathrm{a}=\mathrm{C}$

Dalam setiap pengukuran terdapat kesalahan atau ketidakpastian. Untuk menentukan nilai konstanta wien dianalisis beberapa kesalahan atau ketidakpastian supaya mendapatkan hasil yang mendekati kebenaran. Nilai ralat dapat diperoleh dari grafik, maka akan diperoleh persamaan

$$
\widehat{y_{l}}=a x_{i}
$$

Hasil dari persamaan tersebut dapat digunakan untuk menentukan pasangan titik-titik (xi,yi) yang akan memberi garis lurus pendekatan terbaik. Ketidakpastian didapat dengan persamaan:

$$
S_{\hat{y}}=\frac{1}{N} \sqrt{\frac{N \Sigma y_{i}^{2}-\left(\Sigma y_{i}\right)^{2}}{N-1}}
$$

Karena $\mathrm{C}=\mathrm{a}$, maka ralat konstanta wien $\mathrm{Sc}=\mathrm{Sa}$. Ketidakpastian relatif menentukan ketelitian pengukuran. Ketidakpastian relatif didapat dari persamaan berikut (Djonoputro,1984).

$$
C_{\text {relatif }}=\left|\frac{C_{\text {eksperimen }}-C_{\text {teori }}}{C_{\text {teori }}}\right| \times 100 \%
$$

\section{Simpulan}

Dari percobaan tersebut dapat disimpulkan bahwa berdasarkan analisis data yang telah dilakukan, nilai a sebesar 0.014 dengan besarnya nilai Konstanta Wien dari data tersebut $2.898 \times 10^{-3} \mathrm{mK}$ dengan ralat relatif sebesar $5 \%$ atau 0,05. Dengan demikian pengambilan data dengan PhET Simulation nilai yang diperoleh sesuai dengan nilai konstanta Wien secara teori.

\section{Referensi}

Fithriani S L, Halim A, and Khaldun I. 2016 Penggunaan Media Simulasi Phet Dengan Pendekatan Inkuiri Terbimbing Untuk Meningkatkan Keterampilan Berpikir Kritis Siswa Pada Pokok Bahasan Kalor Di SMA Negeri 12 Banda Aceh. J. Pendidik. Sains Indones.4, 2 p. 45- 52. 
Kustija, Jaja. - . Modul $V$ Fisika Modern. http://file.upi.edu/Direktori/FPTK/JUR. PEND. TEKNIK ELEKTRO/1959123119850 31-JAJA KUSTIJA/MODUL $\vee$ fisika modern.pdf (diakses pada: Senin, 25 November 2019)

Mubarrok M F dan Mulyaningsih S. 2014 Penerapan Pembelajaran Fisika pada Materi Cahaya dengan Media PhET Simulations Untuk Meningkatkan Pemahaman Konsep Siswa di SMP J. Inov. Pendidik. Fis.3, 1 p. 76-80.

Prihatiningtyas S, Prastowo T, and Jatmiko B. 2013 Implementasi Simulasi PhET dan KIT Sederhana Untuk Mengajarkan Keterampilan Psikomotor Siswa pada Pokok Bahasan Alat Optik J. Pendidik. IPA Indones.2, 1 p. 1822.

Sutarno, Erwin and Hayat, M S. 2017 Radiasi Benda Hitam dan Efek Fotolistrik Sebagai Konsep Revolusi Saintifik Dalam Perkembangan Teori Kuantum Cahaya J. Ilm. Multi Sci.IX, 2 p. 51-58

Swandi A, Nurul S Lj H, dan Pembelajaran A M. 2014 Pengembangan Media Pembelajaran Laboratorium Virtual untuk Mengatasi Miskonsepsi Pada Materi Fisika Inti di SMAN 1 Binamu, Jeneponto J. Fis. Indones.XVIII, 52 p. 20-24. 